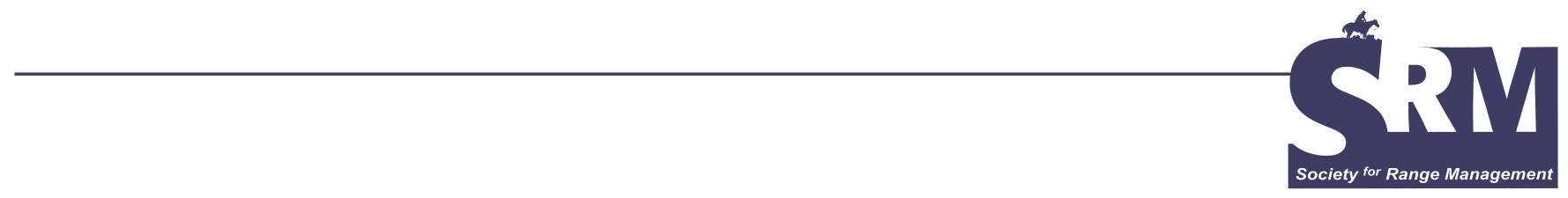

\title{
A History of Range Use in British Columbia
}

\section{By Alfred H. Bawtree}

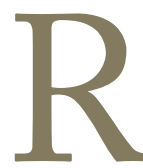

ange use in British Columbia (BC) is closely allied to the various distinctive vegetative and geographical zones of the province. $\mathrm{BC}$ rangelands generally lie between the Rocky Mountains to the east and the Coast or Cascade mountains to the west. An exception is the Peace River zone in northeastern BC, which is on the east side of the Rocky Mountains. Most of the land area lies in the Central and Northern zone, a vast area dominated by coniferous forest with patches of subalpine and alpine vegetation, aspen groves, wet meadows, and swamps. The Southern Interior zone is the warmest and driest zone and contains virtually all the native grassland in the province. Forests dominate all of these zones and consequently most of the rangeland has been greatly influenced by periodic fires and, in more recent times, by logging.

\section{The Southern Interior Zone}

The earliest fur traders to explore the Southern Interior reported that the native people possessed horses and made good use of them, including eating them. It is believed that horses first entered the province from the United States during the first half of the 18th century. The native grass provided sufficient forage for them in all but the most severe winters. Horse numbers were greatly reduced in severely cold winters with deep snow.

Prior to the exploration by the fur traders, there were deer, elk, and bighorn sheep, but it seems that their numbers fluctuated greatly through the years. Written records from the early 1800 s report very few native ungulates. Elk disappeared from most of the range about that time, probably because of a very severe winter, although the recent acquisition of horses and guns by the natives may also have played a part.

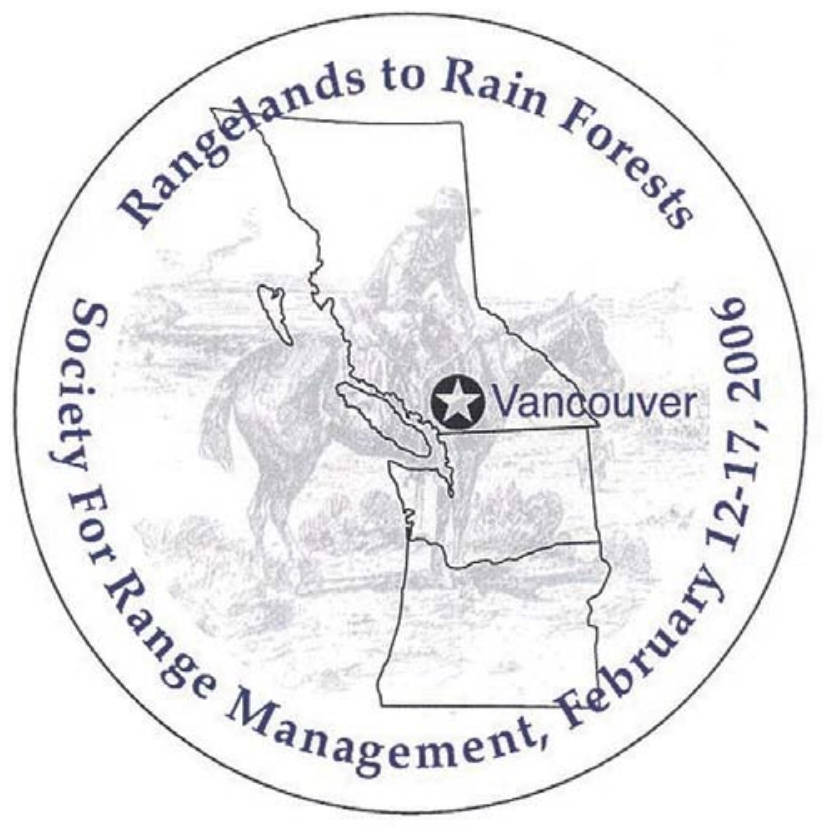

The discovery of gold in 1858 initiated the first large influx of people and cattle into the province. Most of the cattle were herded through the Southern Interior to the gold fields by way of the Columbia, Okanagan, and Kootenay river valleys from Washington, Oregon, and Montana. The bunchgrass ranges in the hot, dry valleys attracted some people to settle on the land and commence raising horses and cattle. The rapidly growing populations in Vancouver and Victoria provided a market for beef and horses, but transport to those markets entailed difficult drives along steep and nar- 


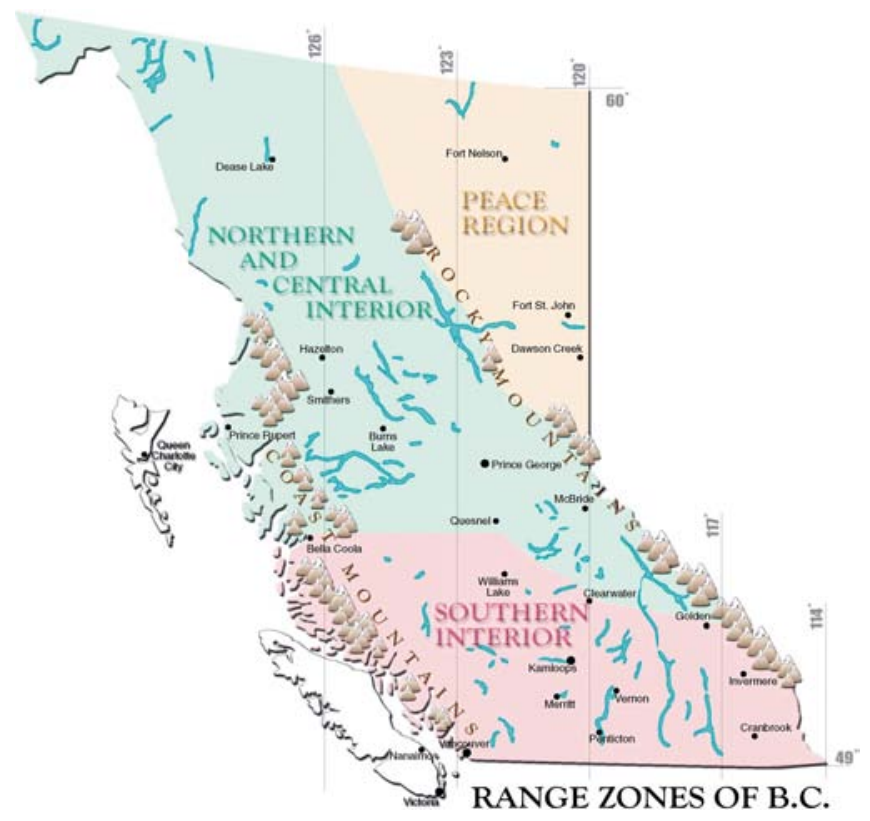

row trails over the Cascade Mountains. The completion of the Cariboo wagon road in 1863 and the trans-Canada Canadian Pacific Railway in 1885 greatly facilitated the growth of the Southern Interior cattle industry. Cattle and horse numbers grew rapidly in the Southern Interior during the latter half of the 19th century but some severe winters killed many animals and indicated that supplemental feeding was required. By the turn of the century overgrazing was evident along major drive routes. Cattle and horses grazed the grasslands only, with very little grazing occurring in the forest or at upper elevations. After 1900, there was a gradual increase in grazing on forest range and an increase in hay production and fencing. Season-long grazing was the general practice for cattle, whereas horses grazed yearlong.

During the war years of 1914 to 1918, ranchers were encouraged to increase beef production, cattle numbers increased, and the grasslands suffered. Following the war there was an increasing awareness of overgrazing on the grasslands. Hay production, herding, fencing, and irrigation increased and beef cattle numbers increased from 100,000 in 1915 to 190,000 in 1917. Grasshoppers, abandoned horses, and droughts added to the problems already present on the grasslands during the interval between wars. Ranchers were now fully aware of the deteriorated condition of the grasslands but the solutions were less evident. Assistance was requested from governments, which resulted in the opening of the range research substation at Kamloops in 1935. Several reports on range conditions were prepared and partial solutions to the problems were presented. An abundance of timber milk vetch, a native plant with poisonous qualities, was identified about this time. Its abundance in the forest discouraged the use of forest ranges by cattle. Much of the best grassland was invaded by annual cheatgrass (also known as downy brome) at this time and burning was undertaken to control it. Cattle num-

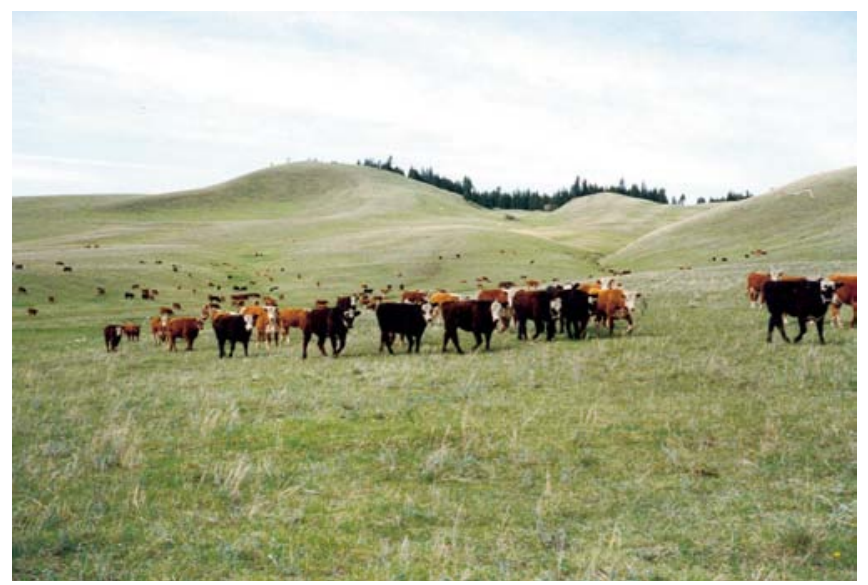

bers remained relatively static during the depression years of the thirties, but domestic sheep numbers increased rapidly as access was opened to subalpine and alpine ranges for summer grazing. The population of horses also increased during this period and contributed to the yearlong grazing.

During the war of 1939 to 1945 , ranchers were again encouraged to increase beef production. Authorized use of public range by yearling and mature cattle increased from 101,000 head in 1940 to 156,000 in 1945 . The authorized season of use on the public lands was usually 6 months. Cattle were grazed on private lands for a further 1 to 6 months depending upon location. In more recent years, the grazing of horses on public grazing lands in the Southern Interior has become insignificant, and cattle numbers have remained almost static. Horses are now generally confined to private lands where native range and pasture is supplemented with hay and grain. Stricter administration of the public rangelands has resulted in a shortening of the grazing season. The Forest Service has become very efficient at wildfire control in recent decades, which has resulted in significantly increasing forest density and encroachment into the grasslands. This trend has been partially offset by tree harvesting. The condition of the grasslands has gradually improved as better range practices, such as rotation grazing systems, have come into common use. Large native cool-season bunchgrasses now dominate most of the grasslands and extensive

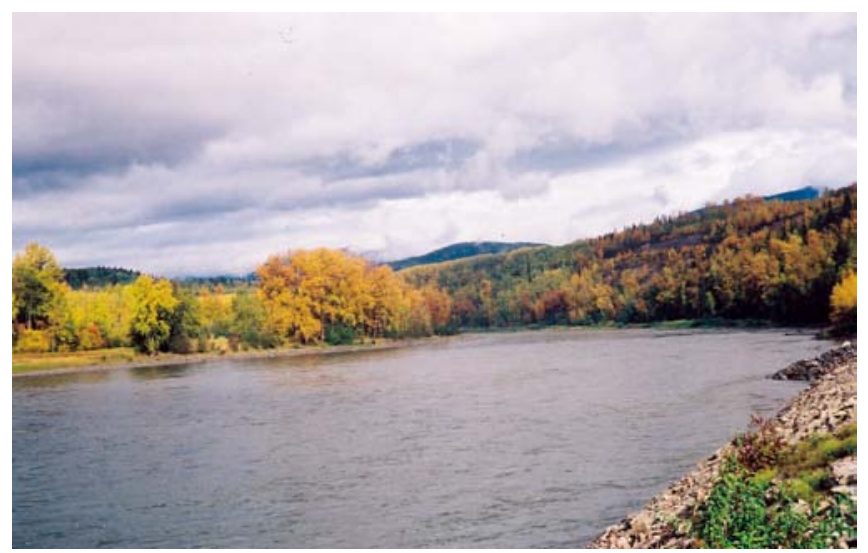




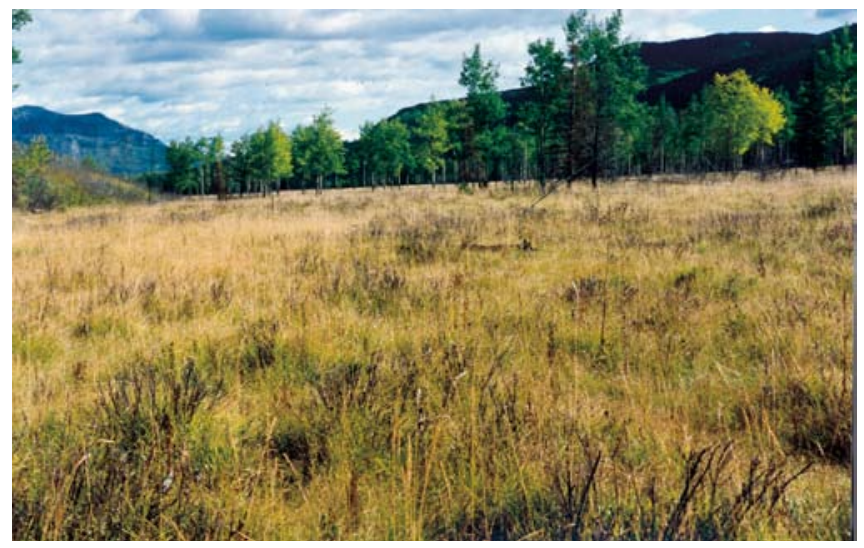

areas of downy brome are no longer found. Deer, moose, elk, bighorn sheep, and mountain goats still graze in the Southern Interior. Elk, moose, and bighorn sheep all appear to have significantly increased in local areas since 1800 .

\section{The Central and Northern Zone}

In 1793, Alexander Mackenzie led a party of men from Eastern Canada to the Pacific Ocean at present day Bella Coola. He traveled up the Peace River, which drains to the Arctic Ocean and crossed the continental divide onto the Fraser River system, which drains to the Pacific. He reported an abundance of bison, elk, and deer east of the Rocky Mountains but scarce wildlife on the Pacific slope. He makes no mention of horses and he and his party were forced to carry their goods on their backs where it was impossible to travel by canoe. Most of his travels in $\mathrm{BC}$ were in the Central and Northern zone where he found dense forests, wet weather, and little wildlife. The native people depended on fish for meat.

Very little agriculture is practiced in the Central and Northern zone except in the vicinity of Prince George and northwesterly along the Canadian National Railway to the Coast Mountains. The Lakes District, which lies in the geographical center of BC, was settled about 1907 around the time the railway was being built. Native meadows provided some winter feed for horses, which were needed for the development of homesteads, surveys, road and railway construction, etc. Although ranching has been carried on in central $\mathrm{BC}$ for almost a century, its development has been slow. This seems to be because of the long feeding season, which lasts for 5 to 6 months, and the distance to markets. The native forage of grass and forbs is of excellent quality and locally abundant, but September frost severely reduces its value.

Throughout the whole of the Central and Northern zone there are occasional breaks in the forest canopy where ungulates may forage. Water is abundant in the form of creeks, rivers, and lakes and a little forage is frequently available in the adjacent riparian areas. Numerous mountains rise above the forest zone and forage is found in subalpine and alpine locations.

Scattered populations of deer, mountain goats, caribou, and stone sheep were present before the arrival of Europeans and may still be found. Moose were rare or absent when
Europeans arrived but became abundant about 1930 and are still common. Horses are commonly kept on private lands for use on the ranches, for recreational purposes and for packing hunting and recreational parties in the mountains.

\section{The Peace River Zone}

Alexander Mackenzie was employed by the North-West (fur trading) Company in 1793 when he canoed up the Peace River into what is now northeastern BC. His objective was to explore the country for fur-bearing animals. Later, forts were built where traders were stationed to trade goods to the natives for the furs they delivered. One of the early forts was named Fort St. John, which is now the largest city in the Peace River zone. The business of fur trading was about the only commerce carried on in the Peace River zone for over a century after establishment of the first forts. The area was cut off from the remainder of $\mathrm{BC}$ by the Rocky Mountains and it was not until 1952 that a decent road was built from Prince George through the Pine Pass to Chetwynd and the Peace River country.

Mackenzie saw large numbers of elk and bison grazing among the aspens along the Peace River in 1793. Moose were also common in the Peace River zone at that time. The bison seem to have disappeared about the same time as they did elsewhere. Elk, bighorn sheep, deer, and moose are still locally common and bison have been reintroduced.

Settlement of the Peace River zone started in the 1920s. At first the access was from Alberta over muddy trails. The extension of the Northern Alberta Railway to Dawson Creek, BC, in 1931 greatly improved access and the opportunity to export farm products to Edmonton, Alberta, and markets farther south and east. Grain-growing proved difficult because of the short growing season and unreliable harvesting weather. However, grain is still grown abundantly despite the problems of harvesting.

During the 1950s, community pastures were reserved on public lands with marginal agricultural potential. Their purpose was to promote the production of livestock and diversification of agricultural production. They were also intended to provide summer grazing at a reasonable cost and to reduce burning of the forest. Burning was a general practice used to clear the forest and improve pasturage for livestock and wildlife. Forest fires were greatly reduced in the farming area after this time but were continued in the mountains to maintain or improve wildlife habitat. The abundance of game animals and the spectacular scenery in the mountains have attracted worldwide attention from hunters and tourists. Many horses are used by guides to pack the hunters and tourists into the mountains. Horses were formerly used extensively in the development of farms and in the construction of roads and railways. Machinery has replaced horses on the farm and for construction but they are still in demand for recreation, packing, and herding.

Rangelands in the Peace River Zone are primarily under an aspen canopy. Nonforested range is present on some 
south-facing slopes at low elevations and on the eastern slopes of the Rocky Mountains where forest cover is reduced or absent because of frequent fires and high elevation.

Cattle and horses graze the improved pastures on both public and private lands as well as in the aspen lands where the canopy is not too thick. Cattle numbers have been increasing steadily for the past 50 years in the Peace River zone, which now constitutes an important part of the beef production in $\mathrm{BC}$.

Author is Range Specialist with 50 years' experience, retired from the BC Ministry of Agriculture and Lands, Kamloops, British Columbia, Canada.

\section{Additional Reading}

Chance, D. H. 1986. People of the Falls. Colville, WA: Dons Printery. 110 p.

Cox, D. 1993. Pioneering the Peace. Penticton, BC, Canada: Skookum Publications. 64 p.

MackenZIE, A. 1802. Voyages from Montreal through the continent of North America to the Frozen and Pacific Oceans. Philadelphia, PA: John Morgan.

Shelford, A., AND C. SHELFORD. 1988. We pioneered. Victoria, BC, Canada: Orca Book Publishers Ltd. 214 p.

Steves, J., AND A. MCLEAn. 1989. History of the Cattle Industry in British Columbia. Rangelands 11: 62-64.

WEIR, T. R. 1955. Ranching in the Southern Interior Plateau of British Columbia. Ottawa, Canada: Queens Printer. 124 p.

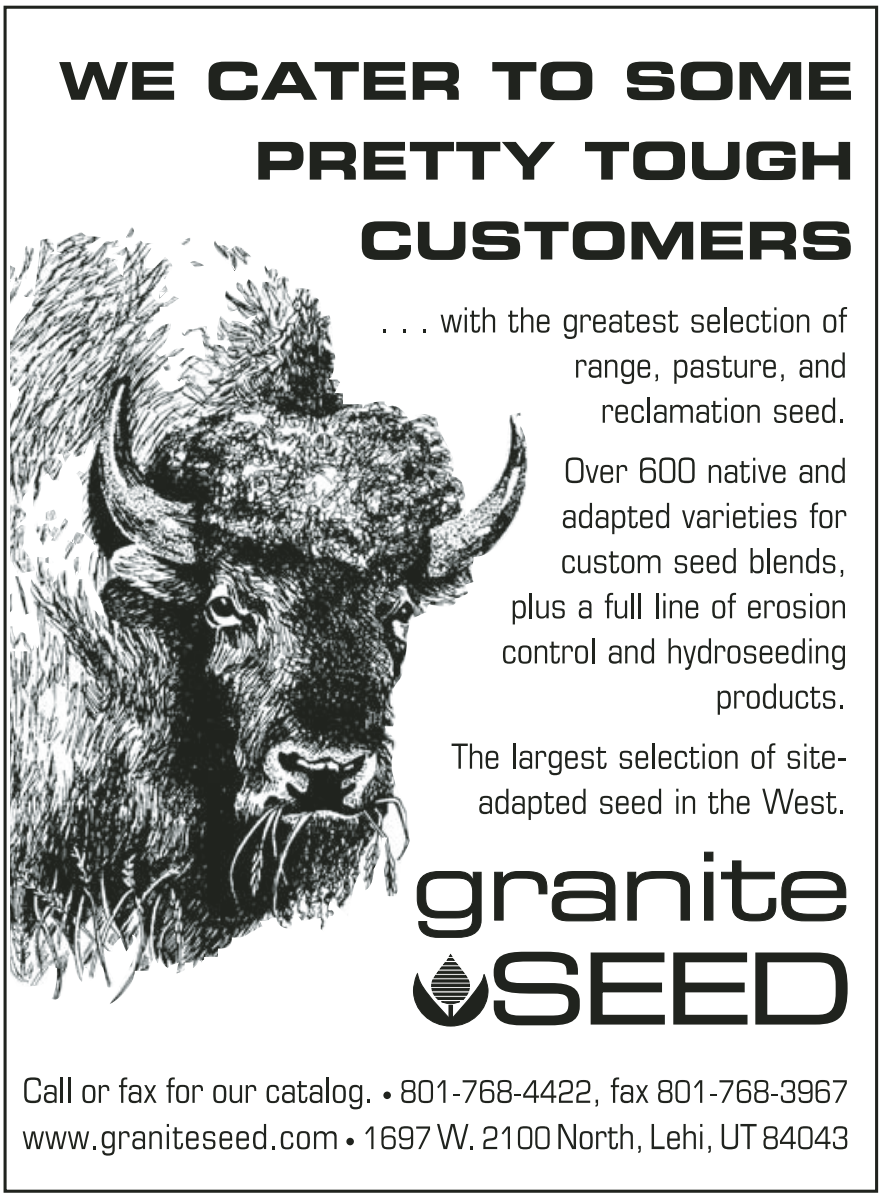

